\title{
A legislative aspect of artificial fruit ripening in a developing country like Bangladesh
}

\author{
Md. Nazibul Islam ${ }^{1}$, Abul Hasnat Md. Sazedur Rahman ${ }^{1}$, Mehnaz Mursalat ${ }^{1}$, Asif Hasan Rony ${ }^{1}$, Mohidus \\ Samad Khan ${ }^{I}$ \\ ${ }^{l}$ Department of Chemical Engineering, Bangladesh University of Engineering and Technology (BUET), Dhaka-1000, \\ Bangladesh. Article Info: Submitted on May 10, 2015, Accepted on August 18, 2015.
}

\begin{abstract}
Fruit ripening is a natural process in which a fruit goes through various physical and chemical changes and gradually becomes sweet, coloured, soft and palatable. However, this natural process can also be stimulated by using artificial fruit ripening agents. Farmers and vendors often use artificial ripening agents to control fruit ripening rate. However, because of the potential health hazard related to the ripening agents, artificial fruit ripening process is highly debateable throughout the world. There are existing laws and guidelines to control artificial fruit ripening process. This article deals with the legal aspects of artificial fruit ripening and fruit adulteration in Bangladesh. Different laws and acts to control and prohibit fruit ripening and adulteration using hazardous chemicals are discussed in detailed here. Laws from different developed and developing countries are also listed and discussed here. Furthermore, the technical and economic issues related to the artificial fruit ripening are addressed in this study. This article aims to develop awareness among different stakeholders since it will take the active participation of the government agencies, policymakers, farmers, vendors and scientists to address different aspects of artificial fruit ripening issues and to provide an effective solution.
\end{abstract}

Keywords: Artificial fruit ripening; Legislations; Supply chain; Economic impact; Law synchronization.

\section{Introduction}

Fruit ripening process can be stimulated using different artificial fruit ripening agents. In the recent years the use of artificial fruit ripening agents has been much prevalent. Artificial ripening agents are used to provide fruits the desired colour and taste in a short span of time. The need of these agents are mostly encountered for commercial purposes i.e., to make the fruits available to the customers even when it is not the season and gain profit in business by selling them. A few recent reports regarding fruit ripening agents have shown great concern regarding health issues. Agents like calcium-carbide, ethopen, and ethylene are used for this purpose. Whether these agents pose any threat to human health or on the surroundings have become a great concern and hence, needs to be addressed. Many of the recent reports that have mentioned about the possible health hazards associated with these chemicals intensify the need to carry out further study regarding the issue.

In the recent days the consumers have become more health conscious than before. Hence, in many of the countries around the world there are specific laws and regulations regarding the usage of these substances. Even though the terms and conditions of the corresponding legislations vary from country to country, the major objective to enact such laws is to control or prohibit the usage of the chemicals as ripening agents.
There are different economic and technological factors related to the artificial fruit ripening issues. Along with providing legislative guidelines, technologically developed nations are also providing technical assistance to the farmers and vendors to produce and supply ripe fruits that are safe for human health.

The prime objective of this article is to compile and discuss the legal status of artificial fruit ripening in Bangladesh, and to compare and analyze those with respect to relevant laws from other developed and developing countries including USA, UK, India, Pakistan, Nepal and Sri-Lanka. This article also aims to address the economic and technological issues, which may influence the fruit ripening practice and corresponding laws.

\section{Artificial Fruit Ripening and Possible Health Hazard}

Ethylene, a naturally produced hormone within fruit, regulates fruit ripening by initiating and/or controlling a series of chemical and biochemical activities. Ethylene regulates fruit ripening by coordinating the genes responsible for the following activities: increase in the rate of respiration, autocatalytic ethylene production, chlorophyll degradation, carotenoid synthesis alongside conversion of starch to sugar, increased activity of cell-wall-degrading enzymes, changing the colour, texture aroma and flavour of the 


\section{Chemical Engineering Research Bulletin 18(2015) 30-37}

fruit. $^{2,3}$ Various chemicals, such as chemically synthesized ethylene, methyl jasmonate, calcium carbide, ethephon and ethylene-glycol can be used to replicate this process artificially. ${ }^{4-7}$

Amongst the widely used artificial ripening agents, ethylene and methyl jasmonate are reported non-toxic for human consumption, however, they are relatively expensive. ${ }^{6}$ Therefore, in countries like Bangladesh, India and Pakistan, low cost chemicals such as calcium carbide, ${ }^{5,6}$ ethylene Glycol$^{7}$ and ethephon ${ }^{4}$ are reported to be used to trigger the ripening process. Once applied on the fruits, calcium carbide comes into the contact of the moisture and releases acetylene gas, which has characteristics similar to ethylene in terms of ripening fruits. ${ }^{6}$ On the other hand, in presence of moisture at neutral $\mathrm{pH}$, ethephon is decomposed into ethylene gas, bi-phosphate ion and chloride ion. ${ }^{8}$ Individually these chemicals can have adverse effect on human health. ${ }^{5-7,9}$ Direct consumption of acetylene has been found to reduce oxygen supply to the brain and can further cause prolonged hypoxia. ${ }^{9}$ Calcium carbide is alkaline in nature and irritates the mucosal tissue in the abdominal region; cases of stomach disorder after eating carbide-ripened mangoes has been reported. ${ }^{5}$ Workers are in direct contact with calcium carbide when applying it to fruits. This may pose a serious health threat as impurities like arsenic and phosphorus found in industrial grade calcium carbide, which may cause dizziness, frequent thirst, irritation in mouth and nose, weakness, permanent skin damage difficulty in swallowing, vomiting, skin ulcer, and so forth. ${ }^{5} \mathrm{~A}$ generous consumption of ethylene glycol may cause kidney failure even. ${ }^{7}$

\section{Legal status: Bangladesh}

In Bangladesh, the following government ministries and agencies are responsible for the inspection, examination and control of ripening, harvesting and marketing activities of fresh fruit: ${ }^{10}$

- Ministry of Agriculture; plant protection wing

- Customs; inspection of imported fruits and vegetables

$\begin{array}{ll}- & \text { Mobile court } \\ \text { testing } & \text { Ministry of health; samples collecting and } \\ \text { - } & \text { Ministry of science; pesticide testing. }\end{array}$

There are a number of laws, regulations and standards to support the activities of the above agencies to maintain the quality of the home grown and imported fruits. ${ }^{10-12}$ The relevant laws and acts are -

- Bangladesh Pure Food Ordinance (Amendment) Act 2005
- Agricultural products Market Act, 1950(revised in 1985) and The Bangladesh Standards and Testing Institution Act, 1985

$\begin{array}{ll}\text { - } & \text { The Plant Quarantine Act } 2011 \\ \text { - } & \text { The Mobil Court Act } 2009 \\ \text { - } & \text { Bangladesh Consumer Protection Act } 2009 \\ \text { - } & \text { The penal code of Bangladesh } \\ & \text { Formalin Control Act, } 2014\end{array}$

Amendment of sections 4A and 6A of The Bangladesh Pure Food Ordinance, 1959 (ordinance no LXVIII of 1959) has been proposed to stop adulterations of food. ${ }^{13}$ According to Bangladesh Pure Food Ordinance (Amendment) Act 2005, a new section named 4A has been introduced, which proposes the formation of a National Food Safety Advisory Council (NFSAC), led by the Minister for Ministry of Local Government, Rural Development and Co-operatives. This council advises the Government regarding food safety. Again, section-6A prohibits the sale of any food in which chemicals like calcium carbide, formalin, pesticides (DDT, PCBs oil etc) have been used. ${ }^{14}$

Other rules consist of Agricultural products Market Act, 1950 (revised in 1985) and The Bangladesh Standards and Testing Institution Act, 1985 which relates to the formation of BSTI. ${ }^{15}$ The second ordinance has been amended as The Bangladesh Standards and Testing Institution (Amendment) Act, 2003. With the help of these acts, products having the standard mark are collected by the surveillance team of BSTI directly from the open market and tested in the BSTI laboratories. Representatives from the Consumers Association Bangladesh (CAB) as well as the Chamber of Commerce and industries help the surveillance team to perform the task.

On 20th March 2011 the parliament passed The Plant Quarantine Act $2011^{16}$ to prevent unapproved export and import of plants (which includes parts of plant also). Violation of this law may result in maximum two years of imprisonment or a BDT 500,000 (USD $\$ 6,250$ appx.) fine or even both. This replaces The Destructive Insect and Pest Act, 1914.

According to The Mobil Court Act $2009{ }^{17}$ magistrates have the power to impose maximum sentence of two years to anyone who is found guilty of illegal usage of artificial fruit ripening agents. This gives the power to the magistrates to penalize any person using artificial fruit ripening agents illegally right on the spot.

Furthermore, the Bangladesh Consumer Protection Act 2009, page 2164 prohibits the usage of any substance that is harmful to people; page 2767 of the act further states that a person will be penalized with a sentence of three years, or fined with BDT 200,000 (USD \$2,500 appx.) or both if he is found to mix any substance to - 


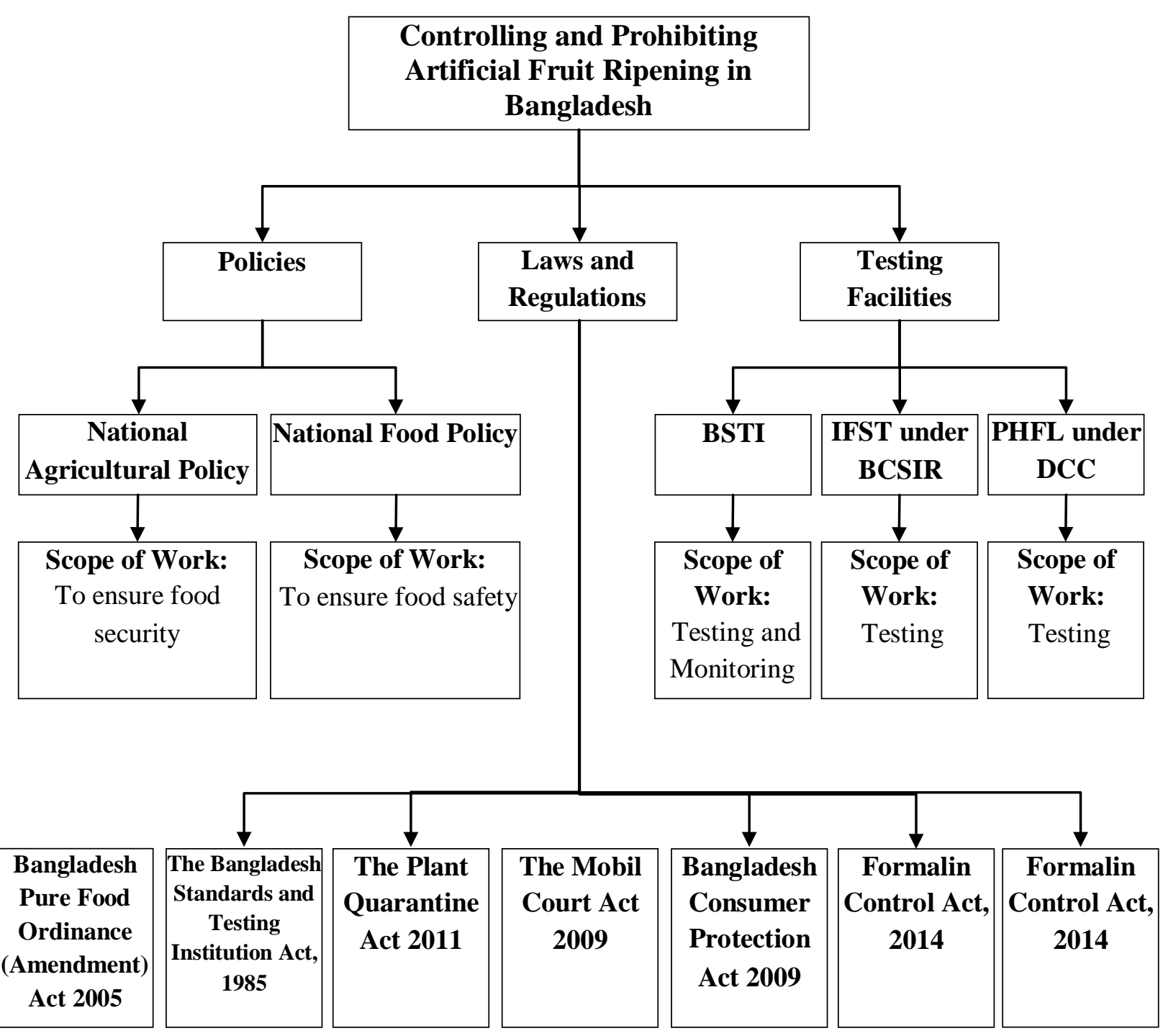

Figure 1: Controlling and Prohibiting Artificial Fruit Ripening in Bangladesh. 


\section{Chemical Engineering Research Bulletin 18(2015) 30-37}

Table 1: Laws and regulations practiced in Asian subcontinent to prohibit artificial fruit ripening and food adulteration.

\begin{tabular}{|c|c|c|}
\hline Country & Laws and Regulations & Aims and Actions \\
\hline \multirow{7}{*}{ Bangladesh } & $\begin{array}{l}\text { Bangladesh Pure Food } \\
\text { Ordinance(Amendment) } \\
\text { Act } 2005\end{array}$ & $\begin{array}{l}\text { Formation of National Food Safety Advisory Council } \\
\text { (NFSAC); } \\
\text { to prohibit using calcium carbide, formalin and pesticides in } \\
\text { foods. }\end{array}$ \\
\hline & $\begin{array}{l}\text { Agricultural products } \\
\text { Market Act, 1950(revised } \\
\text { in 1985) and The } \\
\text { Bangladesh Standards and } \\
\text { Testing Institution Act, } \\
1985\end{array}$ & $\begin{array}{l}\text { To empower Bangladesh Standards and Testing Institution } \\
\text { (BSTI) surveillance teams for field test and monitoring. }\end{array}$ \\
\hline & $\begin{array}{l}\text { The Plant Quarantine Act } \\
2011\end{array}$ & To prevent unapproved import and export of plants. \\
\hline & The Mobil Court Act 2009 & To empower the magistrates of mobile courts. \\
\hline & $\begin{array}{l}\text { Bangladesh Consumer } \\
\text { Protection Act } 2009\end{array}$ & $\begin{array}{l}\text { To prohibit using any substance in food that is harmful for } \\
\text { human health. }\end{array}$ \\
\hline & Formalin Control Act, 2014 & To control the use of Formalin \\
\hline & $\begin{array}{l}\text { The penal code of } \\
\text { Bangladesh }\end{array}$ & To penalize any individual selling illegally ripened fruits. \\
\hline \multirow{3}{*}{ India } & $\begin{array}{l}\text { Prevention of Food } \\
\text { Adulteration Rules } 1955\end{array}$ & \multirow{2}{*}{ To prohibit the use of carbide gas for fruit ripening. } \\
\hline & $\begin{array}{l}\text { Food Safety and Standards } \\
\text { act, } 2006\end{array}$ & \\
\hline & $\begin{array}{l}\text { Food Safety and Standards } \\
\text { Regulations, } 2011\end{array}$ & $\begin{array}{l}\text { Prohibiting the selling artificially ripened fruits using carbide } \\
\text { gas. }\end{array}$ \\
\hline \multirow[t]{2}{*}{ Pakistan } & $\begin{array}{l}\text { West Pakistan Pure Food } \\
\text { Ordinance, } 1960\end{array}$ & To address and limit food adulteration. \\
\hline & $\begin{array}{l}\text { Cantonment Pure Foods } \\
\text { Act, } 1966\end{array}$ & $\begin{array}{l}\text { To address and limit food adulteration at the Cantonment } \\
\text { areas. }\end{array}$ \\
\hline Nepal & $\begin{array}{l}\text { The Nepal Food } \\
\text { Regulation-2027 }\end{array}$ & To prohibit the use of carbide gas for fruit ripening \\
\hline Sri Lanka & Food Act No 26 of 1980 & $\begin{array}{l}\text { To prohibit manufacturing, selling and distributing of any } \\
\text { adulterated food }\end{array}$ \\
\hline
\end{tabular}




\section{Chemical Engineering Research Bulletin 18(2015) 30-37}

the food which has been found lethal to the human body and which has been banned by law. ${ }^{18}$ Since industrial grade calcium carbide may contain traces of arsenic and phosphorous hydride as impurity, ${ }^{6}$ which is hazardous to human health, the usage of calcium carbide as a fruit ripening agent is deemed illegal by this act.

Most importantly according to the penal code of Bangladesh any person who is selling fruits which are illegally ripened may be categorized as "Wrongful Gainer" (the person who helps in illegal fruit ripening) may be categorized as "Dishonest" and legal charges can be bought against them. ${ }^{19}$

In a recent cabinet meeting, the government of Bangladesh has approved the "Formalin Control Bill, 2014", aiming to control the misuse of formalin especially in food items. According to this draft law, any person importing/producing/selling/using formalin without license can be subjected to a maximum lifeimprisonment. He/she can also be fined a maximum of BDT 2 million (USD $\$ 25,000$ appx.) and minimum of Tk. 500,000 (USD \$6,250 appx.). ${ }^{11,12}$ If a license holder breaches any condition of the licence, he/she will be punished with 2-7 years of imprisonment or a fine of BDT 200,000-500,000 (USD \$6,250 - \$2,500 appx.) or both. According to section 27 of the draft law, if a person is found guilty of formalin related offence for the second time, he/she will be subjected to punishment which is be two times heavier. According to section 28, if the offender dies, his/her family members will have to pay the fine. Clause 22 bans the usage of formalin manufacturing machine without licence, clause 23 deals with the person found guilty of cooperating with others for formalin usage and clause 24 deals with the person making false complains. "Formalin Control Bill, 2014" also gives the power to the government to shut down shops/ organizations who are involved in formalin misuse and restrict formalin transportation for less than 15 days. ${ }^{12}$

The chart of the policies, laws and regulations, and testing facilities available to control and prohibit artificial fruit ripening in Bangladesh are shown in Fig. 1.

\section{Legal status: South and East Asia}

In India, the usage of carbide gas for fruit ripening is prohibited under Rule 44 AA of the Prevention of Food Adulteration Rules $1955 .^{20}$ Moreover, the Food Safety and Standards Regulations, 2011 explicitly prohibits selling of fruits, which are artificially ripened by carbide gas. ${ }^{21}$ In addition, selling of unsafe food is punishable under sections 50 and 59 of Food Safety and Standards act, $2006 .^{22}$

The food laws in Pakistan are largely similar to that of Bangladesh because of the shared past of the two countries. In Pakistan, the primary law related to food is West Pakistan Pure Food Ordinance, $1960,{ }^{23}$ which is to some extent similar to the East Pakistan Pure Food Ordinance, 1959 now amended as Bangladesh Pure Food Ordinance (Amendment) Act 2005. Section 6 of this law deals with adulterated food items which is applicable throughout Pakistan (except the cantonments) with minor regional changes. Like Bangladesh, the cantonment areas in Pakistan are governed by Cantonment Pure Foods Act, $1966 .^{24}$ The offences under these acts are classified as first offence, second offence and repeated or large or serious offence. The punishments include fine and/or imprisonment. $^{24}$

In Sri Lanka, under the Food Act No 26 of 1980, no person can manufacture, sell or distribute any food that has any natural deleterious substance added upon it which is injurious to health. ${ }^{25}$

In Nepal, Part 7, rule no 19(d) of The Nepal Food Regulation-2027 has strongly prohibited the usage of carbide gas in ripening of fruits. 5,26

In Malaysia, section 13 of the FOOD ACT 1983, explicitly bans food containing substances injurious to human health. Since carbide ripened fruits may contain substances injurious to human health, ${ }^{9}$ it cannot be used in fruit ripening and any person caught using it can be fined up to one hundred thousand ringgit (USD \$28 thousand appx.) or imprisoned for up to ten years. $^{27}$

The laws and acts practiced in the SAARC countries: Bangladesh, India, Pakistan, Nepal and Sri Lanka, are enlisted in Table 1. From these rules and acts, it is clear that like Bangladesh and other South Asian countries have specific laws which prohibit using calcium carbide and other chemicals as artificial ripening agents which may be hazardous to human health.

\section{Legal status: Developed World}

In different developed countries fruits are allowed to be ripened in artificial fruit ripening chambers. Ethylene is injected to these chambers in a controlled way which helps to instigate the ripening process. ${ }^{6}$ Evidently, the laws in different developed countries do not completely prohibit using artificial ripening agents, and often permit the usage of ethylene gas for artificial fruit ripening. For example: in USA, the United States' NOSB recommends the use of ethylene for postharvest ripening of tropical fruit and degreening of citrus; this is stated in the 'Formal Recommendation by the National Organic Standard Board (NOSB) to the Organic Program (NOP)'. ${ }^{28}$ Similarly, United Kingdom's Soil Association allows the use of ethylene to ripen bananas and kiwi (Soil Association Organic Standards, rev 16.4, June 2011). ${ }^{29}$ 


\section{Chemical Engineering Research Bulletin 18(2015) 30-37}

The International Federation of Organic Agriculture Movements' (IFOAM) also enlists ethylene gas as 'Only for ripening fruits' in IFOAM Indicative List of Substances for Organic Production and Processing. Similarly the Asia Regional Organic Standard (AROS) developed by Global Organic Market Access (GOMA) a project of FAO, IFOAM and UNCTAD (United Nations Conference on Trade and Development) permits the usage of ethylene for the ripening of kiwifruit, bananas and other tropical fruit. ${ }^{30}$

\section{Supply Chain, Economic Impact and Technological Development: Law Synchronization}

In a developing country like Bangladesh, farmers often use artificial ripening agents to sell fruits during the offseason; they also use ripening agents to meet the higher demands during the actual ripening season. Another important reason especially in the developing world is the complex supply chain. In the fiscal year, 2006-2007 Bangladesh produced about 2.74 Million Metric tons of fruits. ${ }^{31}$ In Bangladesh, distributing fruits from the farmers' orchards to consumers' baskets can take several days. In the distribution process fruits are collected from farmers and sent to the local storage points. From local storages (or collection points), fruits are transported to the warehouses of the major cities and remote areas of the country, from where the retailers collect fruits and sell to the customers. Besides, a wide range of fruits are also exported from Bangladesh to different parts of the world. In 2007-2008, Bangladesh exported fruits worth USD\$ 8.64 million, which has increased approximately 10 folds in 5 years (USD\$71.89 million by 2012-2013), and is still growing. ${ }^{32}$ During this time naturally ripened fruit may become over-ripe, and therefore, becomes inedible. Again, the unavailability of sufficient storage facility can also make fruit unfit for sale. It is an economic loss for the fruit-sellers. Hence, to minimize the loss, fruit-sellers sometimes prefer collecting fruits before they are fully ripe, and artificially ripen fruits before selling to the consumers.

However, new technological developments can offer a safer and economically viable means to artificially ripen fruits. Several research groups reported that a mixture of ethepon and sodium hydroxide in water, or a diluted ethylene glycol solution can be used as artificial ripening agents without having noticeable harmful effect on human health . ${ }^{5-7}$

For mass production, ethylene ripening chamber can be the most promising option. Specially designed chambers are already in use in the developed countries to artificially ripen fruits. ${ }^{4}$ Recently, India is trying to utilize the potential of ripening chambers and have already formalized technical standards and protocol for fruit ripening chambers. ${ }^{33}$ Bangladesh can take similar initiative to modernize fruit ripening process in commercial scale. Small and rural farmers can utilize ethereal or glycol solution or set up ripening chambers on a co-operative basis. A fully computerized single ripening chamber of volume $57 \mathrm{~m}^{3}(5.07 \mathrm{~m} \times 3.31 \mathrm{~m} \mathrm{x}$ $3.39 \mathrm{~m})$ may cost approximately USD $\$ 20,000 .^{34}$ However, cheaper manpower and extensive experience in this field can lower the operational cost. ${ }^{35}$ Bangladesh Krishi Bank (the state run agricultural bank) and other NGOs can provide microcredit to farmers for setting up ripening chambers. The government can follow examples of other countries and formalize regulations regarding ethylene chambers.

\section{Conclusion}

Artificial fruit ripening is a complex issue for a country like Bangladesh, which is providing fruits to a population of more than one hundred fifty million, and also exporting fruit items to overseas. In Bangladesh, different laws and acts have been enacted to prohibit the illegal use of harmful artificial ripening agents. However, in spite of having strict laws and acts, the temptation for using artificial ripening agents is evident among the farmers and the vendors because of the high demand of seasonal fruits and possible economic loss during the distribution, To resolve the problem from the root, the related technical and economic issues have to be addressed from the government level. The scenario of the developed world can be regarded as a role model to trigger the practice of using artificial ripening agents in the legal way. India is already working on the technological issues to help farmers and vendors involved in fruit industries. In Bangladesh, the active participation of the government agencies, policymakers, farmers, sellers, consumers and scientists is required to find a fruitful solution for this issue. In addition, mass awareness must be raised among the consumers regarding this complex issue. Media and the lawmakers can play a vital role in this respect.

\section{Acknowledgement}

This research was supported by BCEF Academic Research Fund and BUET CASR Research Grant.

\section{References}

1. T.V. Jayan, "Beware of These Fruits", in The Telegraph, Calcutta. 2011, The Telegraph, India: Calcutta, India.

2. A. Theologis, "One Rotten Apple Spoils the Whole Bushel: The Role of Ethylene in Fruit Ripening Cell," 1992. 70(2): p. 181-184. 


\section{Chemical Engineering Research Bulletin 18(2015) 30-37}

3. J.H. Oetiker and S.F. Yang, "The Role of Ethylene in Fruit Ripenng, in Postharvest Physiology of Fruits," H. Hyodo and A.E. Watada, Editors. 1995, ISHS Acta Horticulturae 398: Kyoto, Japan p. 167-178.

4. M.A. Hakim et al., "Role of Health Hazardous Ethephone in Nutritive Values of Selected Pineapple," Banana and Tomato Journal of Food, Agriculture \& Environment 2012. 10(2): p. 247251.

5. M.W. Siddiqui and R.S. Dhua, "Eating Artificial Ripened Fruits is Harmful." Current Science, 2010. 99(12): p. 1664-1668.

6. A. Ur-Rahman, F.R. Chowdhury and M.B. Alam, "Artificial Ripening: What We are Eating." Journal of Medicine, 2008. 9(1): p. 42-44.

7. R. Goonatilake, "Effects of Diluted Ethylene Glycol as A Fruit-Ripening Agent." Global Journal of Biotechnology \& Biochemistry, 2008. 3(1): p. 8-13.

8. H.P. Le, "Progress and trends in ink-jet printing technology." The Journal of imaging science and technology, 1998. 42(1): p. 49-62.

9. S.A. Fattah and M.Y. Ali, "Carbide Ripened Fruits - A Recent Health Hazard." Faridpur Medical College Journal, 2010. 5(2): p. 37.

10. "Report on a Workshop on Food Inspection Arrangements in Bangladesh," F.a.A.O.o.t.U. Nations, Editor. 2010, Food and Agriculture Organization of the United Nations: Dhaka, Bangladesh. p. 1-27.

11. "Anti-formalin law gets Cabinet's final approval," in The Independent 2014, Independent Publications Limited: http://www.theindependentbd.com.

12. "Cabinet okays Formalin Control Act, 2014," in Daily Sun. 2014, East West Media Group Limited: http://www.daily-sun.com/.

13. "A Report Regarding a Proposed Amendment of Certain Sections of the Bangladesh Pure Food Ordinance," 1959 (Ordinance No. LXVIII of 1959), L.C.o. Bangladesh, Editor. 2007, Law Commission of Bangladesh, GoB: Dhaka, Bangladesh.

14. "Bangladesh Pure Food Ordinance (Amendment) Act 2005," B. Parliament, Editor. 2005, Bangladesh Parliament Bangladesh Government Press.

15. W. Shen and R. Urquhart, "Inkjet ink and paper Interaction," in Australian Printer. 2004.

16. Plant Quarantine Act. 2011, Bangladesh Government

17. Mobile Court Act, J.a.P.A. Ministry of Law, Editor. 2009, Legislative and Parliamentary Affairs Division.
18. "Consumer Rights Protection Act 2009," B. Parlliament, Editor. 2009, Bangladesh Parliament: Bangladesh Government Press.

19. "THE PENAL CODE," M.o.L.J.a.P. Affairs, Editor. 1860, Legislative and Parliamentary Affairs Division.

20. "PREVENTION OF FOOD ADULTERA-TION RULES. 1955," Gazette of India.

21. "FOOD SAFETY AND STANDARDS (PROHIBITION AND RESTRICTIONS ON SALES) REGULATIONS," F.S.a.S.A.o. India, Editor. 2011, MINISTRY OF HEALTH AND FAMILY WELFARE: New Delhi.

22. "FOOD SAFETY AND STANDARDS ACT," M.O.L.A. JUSTICE, Editor. 2006.

23. "THE WEST PAKISTAN PURE FOOD ORDINANCE." 1960.

24. M.S. Khan and A. Hafeez, "CONSUMER LAWS IN PAKISTAN," 1999.

25. "The Gazette of the Democratic Socialist Republic of Sri Lanka: The Food Act, No. 26 of 1980. 1990," The Ministry of Health: Colombo, Srilanka.

26. "The Food (First Amendment) Regulation," 2027, D.o.F.T.a.Q. Control, Editor. 1970, Ministry of Agriculture: Nepal Gazette.

27. "FOOD ACT 1983, P.N.M. BERHAD," Editor. 2006, THE COMMISSIONER OF LAW REVISION, MALAYSIA.

28. D.G. Giacomini, "Formal Recommenda-tion by the National organic Standard Board (NOSB) to the National Organic Program (NOP).” 2012, U.S. Department of Agriculture: USA.

29. "Soil Association Organic Standards: Food and Drink. 2011," Soil Association. p. 77.

30. FAO, IFOAM, and UNCTD, ASIA REGIONAL ORGANIC STANDARD. 2012, United Nations Conference on Trade and Development (UNCTAD), Food and Agriculture Organization of the United Nations (FAO) and International Federation of Organic Agriculture Movements (IFOAM).

31. "Annual Agriculture Statistics," B.B.O.S. AGRICULTURE WING, Editor. 2007.

32. "Analysis of fruits and vegetables export data," M.o.A. Horticulture Export Development Foundation, Government of the People's Republic of Bangladesh, Editor. 2013.

33. N. H. Board, "Technical Standards and Protocol for the Fruit Ripening Chamber in India. 2011," Cold Chain Development Cell.

34. M. Impianti, "Computerised Banana Ripening Rooms, Net Price List, M.I. S.r.t.,” Editor. 2011: Rome, Italy.

35. "Bangladesh and Europe 2012. 2012," Dhaka, Bangladesh: European Union. 
Chemical Engineering Research Bulletin 18(2015) 30-37

Available online at http://www.banglajol.info/index.php/CERB

Publisher: Department of Chemical Engineering, Bangladesh University of Engineering and Technology (BUET). Review \&Publication: A submitted original manuscript is taken into review only if the uniqueness is found to be more than $85 \%$ in plag-scanning and selected for publication by the complete acceptance from at least two reviewers out of three. Home Page: http://www.banglajol.info/index.php/CERB . Indexed by Chemical Abstract Service (CAS), CEABA-VtB, Google Scholar, Scopus and DOAJ 